Primljen / Received: 28.10.2013.

Ispravljen / Corrected: 6.7.2014.

Prihvaćen / Accepted: 27.7.2014.

Dostupno online / Available online: 10.9.2014.

\section{Nove smjernice koncipiranja željezničkih kolodvora}

Autori:

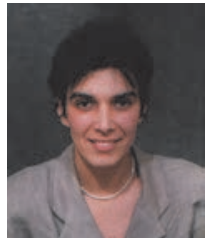

Dr.sc. Ksenija N. Stevanović, dipl.ing.arh.

Sveučilište u Beogradu

Arhitektonski fakultet

thestecats@yahoo.com

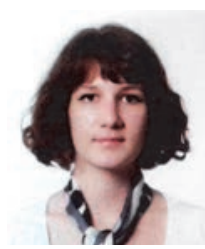

Milena V. Stevanović, dipl.ing.arh.

Ecole Polytechnique de Bruxelles

Service BATir Universite Libre de Bruxelles Milena Stevanovic@ulb.ac.be
Stručni rad

Ksenija N. Stevanović, Milena V. Stevanović

\section{Nove smjernice koncipiranja željezničkih kolodvora}

Održivi razvoj prometa i gradova, objedinjavanje vidova transporta, preporod željezničkog prometa, utjecali su na izgradnju velikog broja željezničkih kolodvora posljednjih desetljeća. Multimodalni kolodvori, unaprijeđenih koncepata i integrirani u urbanu matricu grada, postaju novi centri razvoja. U radu se iz aspekta urbanističko-arhitektonske struke analiziraju pozitivna iskustva u izgradnji značajnih željezničkih kolodvora. Rezultati provedenih analiza na primjeru željezničkog kolodvora u Beogradu, prema predloženom morfološkom konceptu, mogu poslužiti kao smjernice u definiranju važnih kolodvora u urbanim sredinama.

Ključne riječi:

željeznički kolodvori, morfološki koncept, prolazni tip kolodvora, integracija s gradom

Professional paper

Ksenija N. Stevanović, Milena V. Stevanović

\section{New directions in the design of railways stations}

Sustainable development of traffic and cities, integration of transport modes, and the renaissance of railway traffic, have led to construction of a great number of railway stations/terminals over the past decades. These multi-modal traffic interchanges, based on advanced concepts and properly integrated in urban matrices, are becoming new focal points of urban development. Recent positive experience in the construction of significant railway stations is presented from the standpoint of urban development. Results obtained during analysis of the Belgrade railway station, which is based on the proposed morphological concept, can be used as guidelines for development of other significant railway stations in urban areas.

Key words:

railway stations, morphological concept, throughway type railway stations, integration in urban matrix

Fachbericht

Ksenija N. Stevanović, Milena V. Stevanović

\section{Neue Richtlinien zum Entwurf von Eisenbahnterminalen}

Die nachhaltige Verkehrs- und Stadtentwicklung, Verbindungen verschiedener Verkehrsnetze, sowie eine Belebung des Bahnverkehrs, wirken sich in den letzten Jahrzehnten auf den Bau vieler Eisenbahnterminale aus. Multimodale Bahnhöfe modernen Konzepts, die in urbane Stadtmatrizen integriert sind, werden zu neuen Entwicklungszentren. In dieser Arbeit werden gute Erfahrungen im Bau bedeutender Eisenbahnterminale aus urbanistischarchitektonischen Blickwinkeln analysiert. Die Resultate am Beispiel des Eisenbahnterminals in Belgrad können, dem vorgeschlagenen morphologischen Konzept folgend, als Richtlinien im Entwurf wichtiger Bahnhöfe in Stadtzentren dienen.

Schlüsselwörter:

Eisenbahnterminale, morphologisches Konzept, Durchfahrtsbahnhof, Stadtintegration 


\section{Uvod}

Održivi razvoj gradova, već godinama aktualna tema za koju se vezuje niz istraživanja, projekata i investicija na globalnoj razini, ukratko se definira kao proces očuvanja gradova na način da svi njegovi korisnici podmiruju svoje potrebe ne ugrožavajći pritom stanje prirodnih sustava ili životne uvjete drugih ljudi, kako u sadašnjem vremenu tako i u budućnosti, [1].

U kontekstu održivog razvoja prometa i gradova tekući su planovi, direktive i projekti vezani za očuvanje gradova u zajedništvu s učinkovitim prometom. Početkom trećeg milenija EU je definirala politiku prometa baziranu na povezivanju različitih vidova transporta, smanjenju zastoja i zagušenja, kao i stavljanje korisnika i njegovih potreba u fokus interesa, [2]. Posebna pažnja se poklanja aktualiziranju i forsiranju korištenja tračničkih sustava, a tako i oživljavanju željezničkog putničkog prometa, kao i integriranju svih vidova prometa u jedinstven i učinkovit sustav. Preporodom željezničkog prometa, zahvaljujući tehnologiji vlakova velikih brzina, ubrzava se stvaranje jedinstvenog prometa na globalnoj razini, [3].

U skladu S navedenim tendencijama održivi grad podrazumijeva afirmaciju tračničkih sustava koji manje onečišćuju sredinu, smanjuju prometne zastoje i pritom su dovoljnih kapaciteta, [4]. Prometni kolodvori (željeznički i autobusni) važne su distribucijske zone i mjesta presjedanja, odnosno povezivanja raznih vidova prometa te ključne točke prometne mreže grada. Ova značajna prometna čvorišta spajaju izvangradski i gradski promet i vrlo su kompleksni za rješavanje jer se nalaze u izgradenoj sredini. Hijerarhijsko uvodenje i grananje javnog prometa obavlja se preko kolodvora koji, ako nude komfor usluga, mogu značajno utjecati na održivost gradova i prometa u njima, [5]. U smislu svih navedenih tendencija i promjena, u središte pozornosti dolaze i željeznička čvorišta u regiji. Beogradski željeznički čvor, kao dio šire željezničke mreže, zatečenim stanjem redefinicije i tranzicije, trebao bi iskoristiti nova, pozitivna iskustva suvremenih kolodvorskih građevina kako bi se postigla kompleksna integracija s gradom.

Posljednja desetljeća obilježena su velikom izgradnjom željezničkih kolodvora u Europi i šire. Ti su prometni terminali uzorni primjeri multimodalnih presjedališta, mjesta lake i brze promjene vidova prometa, koja nude kvalitetnu uslugu javnog prijevoza, adekvatnu upotrebu gradevinskog zemljišta, smanjenje upotrebe putničkog vozila te nadasve prepoznatljivu arhitektonsku pojavnost, [6]. Za razliku od prijašnjih kolodvora koji su u periodu stagnacije željeznice postali zapušteni dijelovi grada, suvremeni kolodvori postaju ekskluzivna središta urbanog razvoja, [7].

Na primjeru novih kolodvora uočava se unaprijeđen koncept prolaznog tipa kolodvora, koji omogućava integraciju s urbanom matricom. Prepoznavanjem i nabrajanjem novih zahtjeva u koncipiranju gradskog kolodvora definiraju se smjernice uobličavanja i važnih postaja centralne zone grada Beograda. Budući da je postojeći Glavni kolodvor još uvijek u funkciji, a na postajama u Prokopu i na Novom Beogradu nedostaju potrebne gradevine, nova iskustva koincidiraju s potrebom konačnog definiranja ovih matičnih prostora metropole.

\section{Odnos kolodvora i grada}

Prometni terminali su posebna mjesta u urbanom tkivu, megastrukture grada, prometni čvorovi velike fluktuacije ljudi, obogaćeni nizom usluga i sadržaja, koji određuju karakter i razvoj čitavih dijelova grada. Osnovna prednost terminala u gradovima je njihova centralna pozicija, laka pristupačnost putnicima, brza promjena vidova prometa, a s aspekta pojavnosti njihovo značenje je u formiranju vizualnog identiteta grada.

Europski gradovi, uglavnom sličnog urbanog razvoja, imaju stare željezničke kolodvore koji su u funkciji i dio su povijesne infrastrukturne i graditeljske tekovine grada. Ovi terminali 19. stoljeća, glamuroznog perioda pojave i razvoja željeznice, sa širenjem gradova i stagnacijom željeznice postali su već odavno nekompatibilni, skupi za održavanje te dijelom remete matricu grada. Ako se radi o čeonim konceptima kolodvora, tada oni zauzimaju goleme površine dragocjenog gradskog zemljišta, ali predstavljaju i barijeru presijecajući mrežu uličnih tokova, [8].

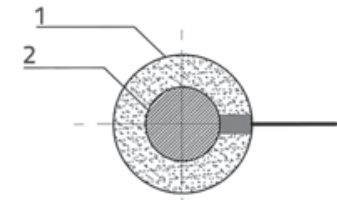

A - čeoni kolodvor (loše rješenje)

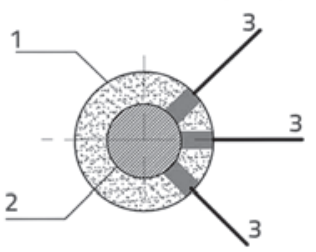

B - umnoženi čeoni kolodvori

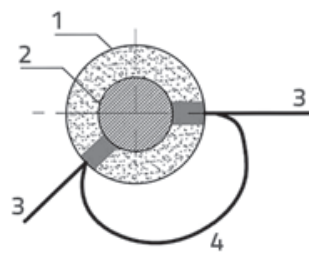

C - povezani čeoni kolodvori

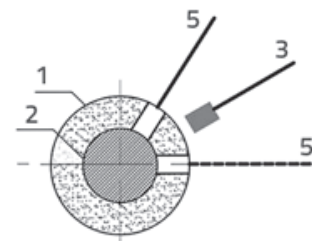

D - izmješten željeznički kolodvor
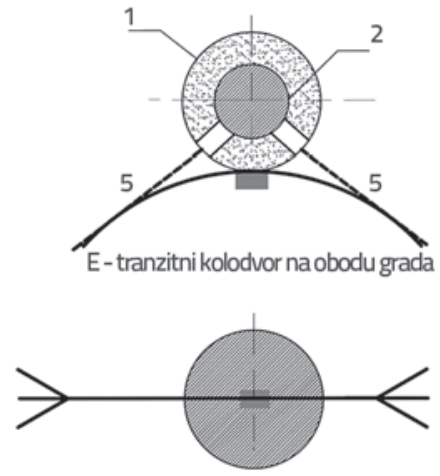

F-prolazni kolodvor u središtu grada (racionalno rješenje)
Slika 1. Razvoj odnosa kolodvora i grada: od pojava, umnožavanja, povezivanja i premještanja kolodvora čeonog tipa do usvajanja i primjene kolodvora prolaznog tipa, [9] 


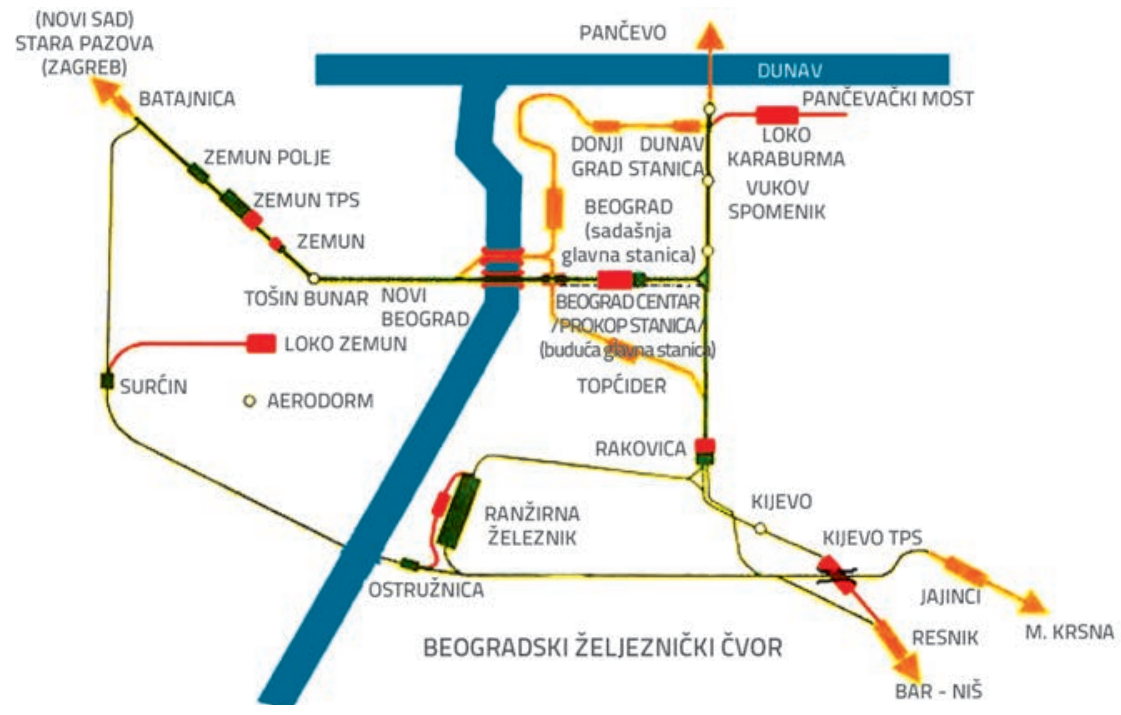

Slika 2. Današnja mreža Beogradskog željezničkog čvora svih smjerova (slika 2.). Sve ostale postaje (prema sjeveru, istoku i jugu) takoder su prolaznog tipa.

Grad bi na taj način imao sustav prolaznih postaja u svemu prema standardima željeznice i suvremenih urbanističkih potreba. Ovaj kapitalni plan i investicija znatnim su dijelom provedeni, ali nedovoljno da sustav profunkcionira u potpunosti, tako da se daljinski putnički promet odvija i dalje preko starog kolodvora. Ovom stanju pridonijela su bitna društveno-politička zbivanja, pa sada, poslije gotovo 40 godina imamo situaciju da su naraslom gradu potrebni i drugi značajni željeznički terminali, [11].
Željeznički kolodvori čeonog tipa, krajnje stanice linija iz raznih pravaca, sve se više napuštaju kako s aspekta prometa, gradevinske struke, tako i planerske i arhitektonskourbanističke. Već krajem 19. stoljeća umnoženi čeoni kolovori povezuju se, premještaju iz centra, a potom se uvode kolodvori prolaznog tipa koji tangiraju grad. Ova geneza razvoja željezničkih čvorova dovela je do optimalnog rješenja: kolodvori prolaznog tipa u centralnoj zoni grada (slika 1.).

Današnja se slika željezničkih kolodvora u europskim metropolama bitno mijenja. Oživljavanjem željezničkog putničkog prometa uvjetovana je i izgradnja novih kolodvora u Europi još krajem prošlog stoljeća. U mnogim gradovima se rade skupe rekonstrukcije starih kolodvora, prilagodavaju se linijama vlakova velikih brzina, kao i prometu grada, stvarajući učinkovitija prometna mjesta za promjenu prometnog sredstva te mjesta koja su obogaćena nizom drugih sadržaja, [10].

S druge strane, došlo je do izgradnje novih kolodvora koncipiranih po suvremenim načelima multimodalnih prometnih čvorišta, koji tangiraju centralnu zonu grada postajući središta razvoja tih dijelova grada.

Grad Beograd se gotovo pola stoljeća "oslobađa" starog Glavnog kolodvora čeonog tipa i gradi novi kolodvor prolaznog tipa. Rekonstrukcija čvora omogućila bi da stari kolodvor, lociran u prostranoj dolini desne obale Save (periferije grada krajem 19. stoljeća), zamijeni glavni kolodvor prolaznog tipa u Prokopu. Povijesni kolodvor višestruko je nepovoljan i za grad i za putnike. Zauzimajući velik prostor svojom kolosiječnom lirom ne dopušta širenje sadržaja uz rijeku niti pristup rijeci, a s druge strane za tranzitne vlakove bitno produžava vrijeme putovanja zbog zadržavanja kompozicija u kolodvoru.

Novi kolodvor Beograd Centar u Prokopu, u široj zoni centra, prolaznog je tipa. Trebao bi povezivati pruge iz

\section{Unaprijedeni koncept kolodvora prolaznog tipa}

Tri osnovna konstitutivna elementa kolodvorskog kompleksa: peronski prostor, kolodvorska zgrada s velikim predvorjem i kolodvorski trg, svojom međusobnom dispozicijom definiraju funkcionalni koncept kolodvora, a time i konačnu morfologiju, [12]. Tipologija kolodvorskih građevina proizišla iz ovog odnosa važna je za arhitektonsko-urbanističku struku jer daje funkcionalno-pojavni karakter cjelini, a dva osnovna tipa su čeoni kolodvori i kolodvori prolaznog tipa, [13].

Čeoni kolodvor, osim što stvara konflikt u matrici grada u pojavnom smislu, svojim gradevinama razdvaja grad od željezničke infrastrukture. To je kolodvor ulazno-izlaznog tipa, njegov pogon iziskuje veći broj kolosijeka u funkciji neizbježnih dugih manevara, a time i veću površinu raspoloživog gradskog zemljišta. No i unatoč svojoj većoj prostornosti, čeoni kolodvor u odnosu na prolazni raspolaže veoma ograničenom propusnom moći. Ako ima više kolodvora toga tipa, što je slučaj s velikim metropolama, grad biva iscjepkan na više sektora te je prekinuta ulična mreža. Suprotno čeonim kolodvorima, kolodvori prolaznog tipa omogućavaju, uz određenu vještinu planera, uvodenje raznih magistralnih ili bilo kojih drugih pruga u gradski prostor time što se spajaju u jedan snop s odgovarajućim brojem kolosijeka. Takva rješenja omogućavaju prilagodavanje željezničke mreže gradskoj prometnoj mreži i urbanističkom planu grada kao obuhvatnoj cjelini, kao i potrebno razdvajanje putničkih pruga od teretnih. Glavni putnički kolodvor u tom slučaju je prolaznog tipa, služi za daleki, brzi i ekspresni promet, ima veliku propusnu sposobnost, omogućava da se sve glavne željezničke pruge uvedu u grad i izvedu iz njega u jednom snopu i njihovo provodenje kroz gradski prostor koji tome najviše odgovara. Svi kolosijeci prolaznih kolodvora su glavni, nema sporednih, imaju veću pristupačnost, trgovi su mogući s obje strane kolodvora ili ispod i iznad, ovisno o vodenju trasa i morfologiji terena, [14]. 
S višestrukim povezivanjem pruga u mreži željeznice primjenjuje se prolazni tip kolodvora. Uvjeti lokacije, morfologija prirodnoga i izgradenoga određuju koji će se podtip kolodvora primijeniti (slika 3.).

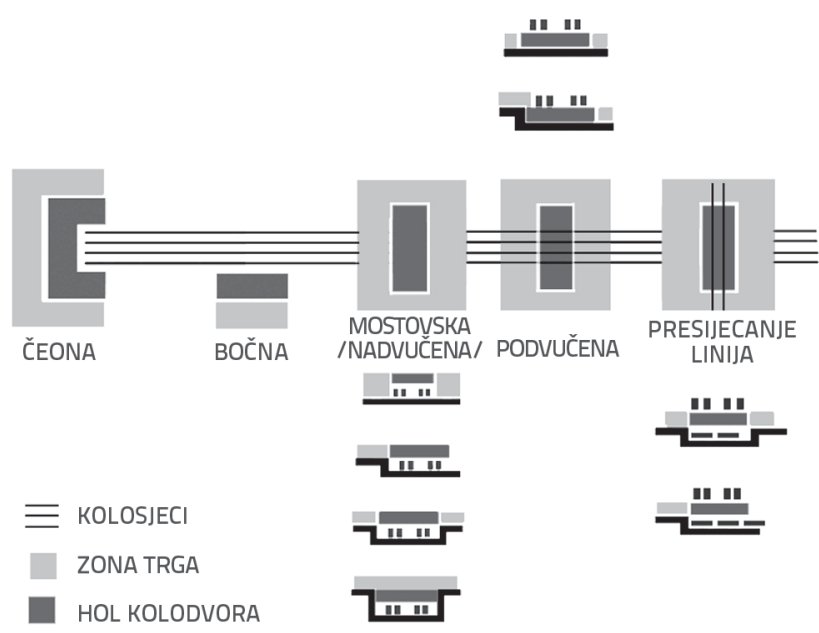

Slika 3. Tipologija kolodvora prema dispoziciji i korelaciji konstitutivnih elemenata u planu i profilu: čeoni tip i modaliteti prolaznog tipa kolodvora, [15]

Prolazni tip kolodvora je najprije podrazumijevao pristup peronima preko nathodnika (pasarela) ili pothodnika, već prema tome je li gradevina na nasipu ili u usjeku, dok je kolodvorska zgrada postavljena bočno. Nedostaci su takvih rešenja brojni: duge putanje od kolodvorskog trga do perona, uski mračni pothodnici ili nathodnici izloženi vanjskim utjecajima, [16]. S vremenom je koncept razrađen tako da kolodvorska zgrada nije više izdvojena u odnosu na perone, već je integrirana u vertikalni plan cijelog kompleksa, tako da su svi dijelovi kolodvora objedinjeni jednim oblikom u jedinstvo arhitektonske pojavnosti (slika 4.), [13, 16].

Ovakav koncept kolodvora, s vertikalnim planom rasporeda sadržaja, višestruko je povoljan ne samo za korisnike, već je funkcionalniji i za grad. Prednosti takvog koncepta su:

- pristup kolodvoru je moguć s više strana i nivoa, odnosno moguće je postojanje više kolodvorskih trgova, što rasterećuje prometne pristupe,

- pružaju brz i lak prijelaz s jednog na drugi vid prometa,

- zauzimaju relativno malu površinu gradskog zemljišta jer koriste vertikalni plan,
- formiraju jedinstvo cjeline u pojavnom i funkcionalnom smislu [17].
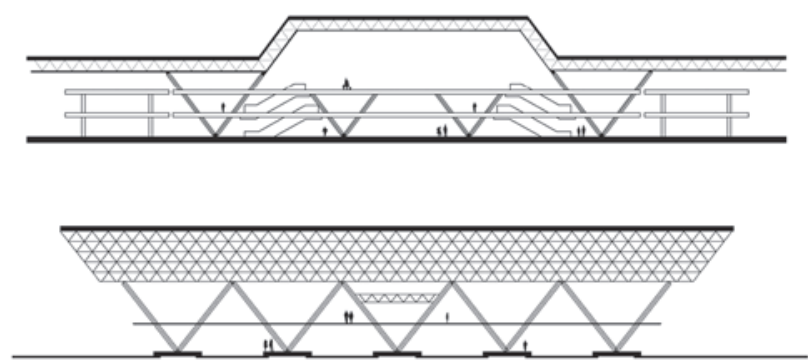

Slika 4. Shema prolaznog tipa kolodvora, jedinstvena cjelina vertikalne superpozicije sadržaja, prvi put primijenjen 1953. godine u natječajnom rješenju kolodvora New Heaven, SAD [16]

Već četvrt stoljeća u Europi, Aziji i šire grade se i rekonstruiraju željeznički kolodvori koji su dolični predstavnici renesanse željeznice i ekonomske moći društva. Primjeri tih kolodvora predstavljaju razrađene modalitete kolodvora prolaznog tipa, bilo da su nadzemne, podzemne ili na križanju linija prigradske i gradske željeznice (slika 5.).

Osim usvojenog koncepta vertikalnog plana, ti kolodvori trebaju ispuniti i druge funkcionalne zahtjeve, a među najvažnijim su:

- formiranje suvremene i efikasne promjene prometnog sredstva,

- osiguranje dobre orijentacije i informacije, stvarajući sigurnost korisnika pri kretanju unutar kolodvora,

- osiguranje obilje dnevnog svijetla koje dopire duboko u najniže nivoe stajališta,

- formiranje kolodvorskog prostora u svojevrsni natkriveni gradski trg tj. prostor obogaćen mnogim privlačnim sadržajima,

- oblikovanje kolodvora u kontekstu čitavog okruženja s ciljem postizanja repernih i prepoznatljivih mjesta u gradovima, [18, 19].

\section{Stanje i potencijal željezničkih postaja u centralnoj zoni Beograda}

Beograd ima značajan položaj za paneuropsku mrežu prometa nalazeći se na željezničkim, cestovnim i vodnim koridorima, kao i mogućnost da postane centrom jugoistočnog
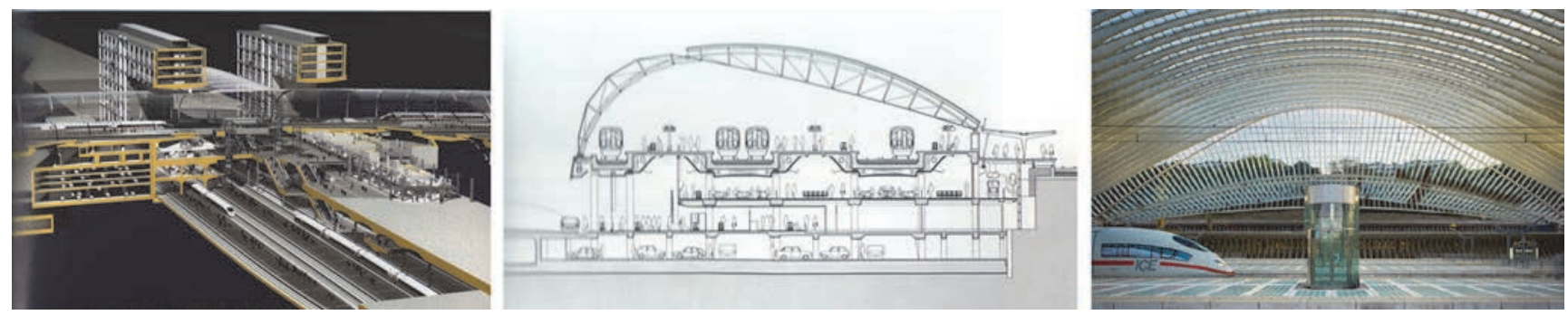

Slika 5. Moderni multimodalni kolodvori: a) Glavni kolodvor u Berlinu (2006.); b) Waterloo kolodvor u Londonu (1994.); c) Novi kolodvor u Liegeu (2011.) 


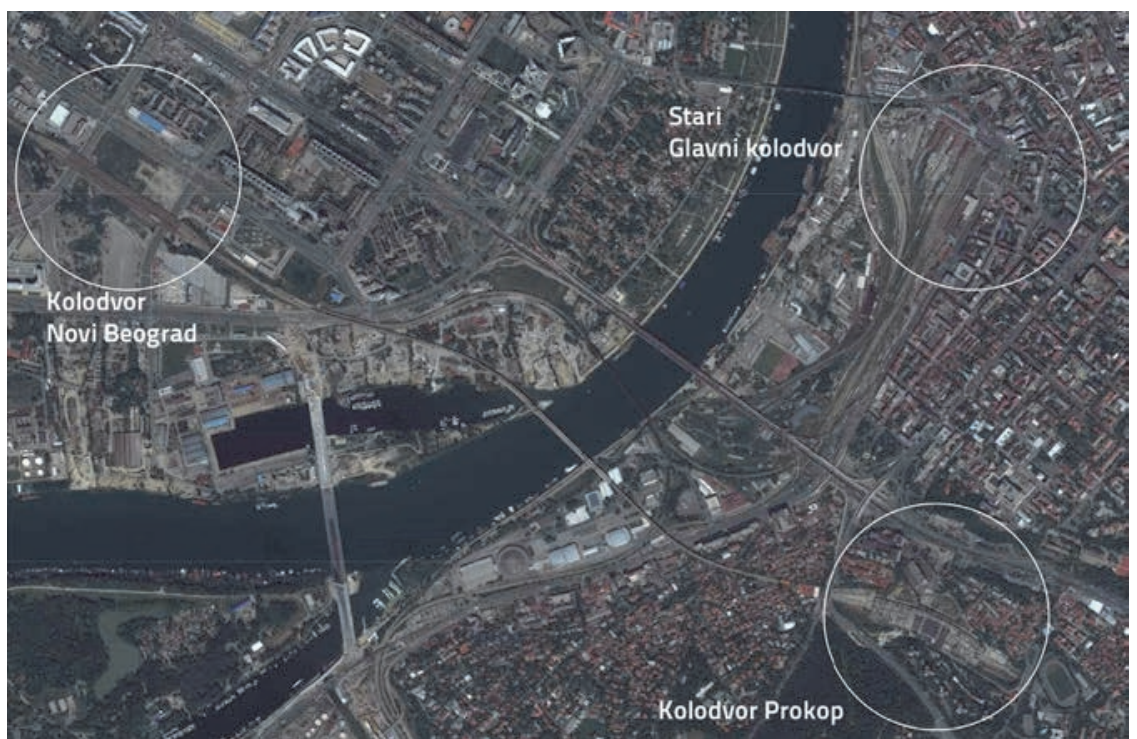

Slika 6. Urbani kontekst kolodvora u centralnim zonama Beograda

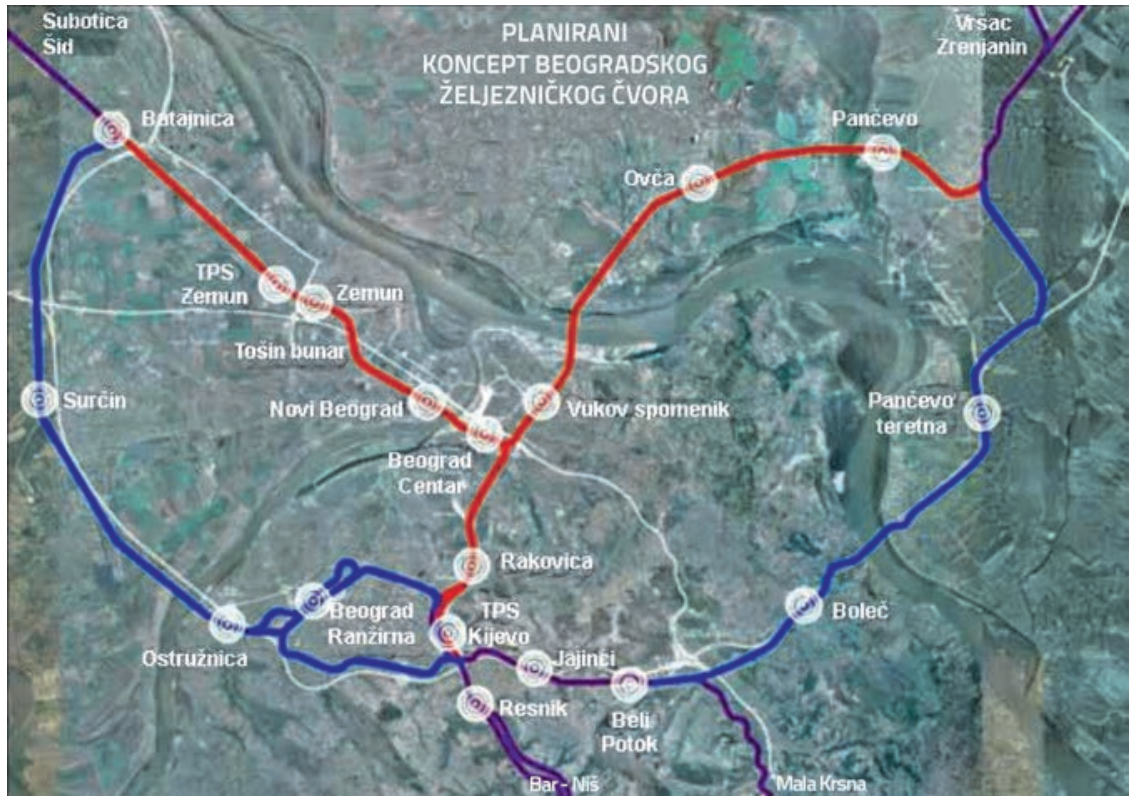

Slika 7. Planirani koncept beogradskog željezničkog čvora s putničkim kolodvorima (crveno) prolaznog tipa kroz središnje gradske zone, [11]

Balkana. Kroz Beograd se ostvaruju veze međunarodnih magistralnih pruga na pravcima sjever-jug i istok-zapad. Unatoč ovim prednostima, rekonstrukcija željezničkog čvora, započeta sedamdesetih godina 20. stoljeća, još nije završena. Grad Beograd, premda je centar željezničke mreže Srbije, već je niz godina u procesu redefiniranja željezničkog čvora. U kontekstu planova i mjera održivosti grada, njegovog prometa, infrastrukture koridora $X$, i tranzicije željeznice, željeznički čvor i njegove postaje tek trebaju biti u središtu interesa. Sadašnja planska dokumentacija (GUP Beograda 2021) nedovoljno tretira ovaj važan dio gradske infrastrukture, [20].
Interdisciplinarni timovi, projektne tvrtke i eksperti u ovom području, prinudeni su, baveći se ovom problematikom, ciklički se uskladivati s promjenama i potrebama grada i investicija. $U$ tom smislu strukovna i šira javnost prati i očekuje definiranje i završetak kolodvorskih zgrada, kao svojevrsnih "ulaznih vrata" grada. Strategija razvoja prometa naglašava važnost Beogradskog željezničkog čvora s glavnim prolaznim putničkim kolodvorom kao čvorištem na europskim pravcima sjever-jug i zapad-istok, [21].

Na bliskom području Beograda, uz rijeku Savu, stari i novi željeznički most i autocestu, pozicionirani su stari Glavni kolodvor, Kolodvor Beograd Centar u Prokopu, kao i Kolodvor Novi Beograd. Navedeni kolodvori su u uzajamnoj korelaciji, a svaki predstavlja neuralgično mjesto za taj dio grada (slika 6.).

Prema planiranom konceptu Beogrdskog željezničkog čvora, putnički se sustav zasniva na prugama koje prolaze kroz centralnu zonu grada sa sjevera prema jugu i istoku. Kontakt s gradom ostvaruje se preko prolaznih kolodvora od kojih su Zemun i Novi Beograd na lijevoj obali rijeke Save, a Beograd Centar i Rakovica na desnoj (slika 7.). Budući da koncept putničkog sustava čvora nije završen, promet se danas odvija starim sustavom čvora, tako da vlakovi izvangradskog sustava željeznice iz svih smjerova stižu u stari putnički kolodvor čeonog tipa, [11].

Premještanjem starog željezničkog kolodvora iz Savskog amfiteatra, uklanjanjem njegove kolosiječne lire (ulazno-izlaznih skretničikih veza) oslobodila bi se velika površina najekskluzivnijega građevinskog zemljišta uz samu rijeku Savu. Trenutačno najaktualnija gradska tema je projekt Beograd na vodi, koji podrazumijeva užurbano premještanje kolosijeka iz Savskog amfiteatra [22]. U zoni tog kolodvora je i Glavni autobusni kolodvor, s 80 polaznih i 20 dolaznih perona i s dnevnim prometom od 1500 autobusa, kao i niz drugih oblika gradskog prometa. Svi ovi sadržaji se šire po horizontalnom planu, dodatno zauzimajući gradsku površinu, a promjenu vida prometnog sredstva čine neučinkovitom, nesagledivom, dugotrajnom i rizičnom, [23]. 

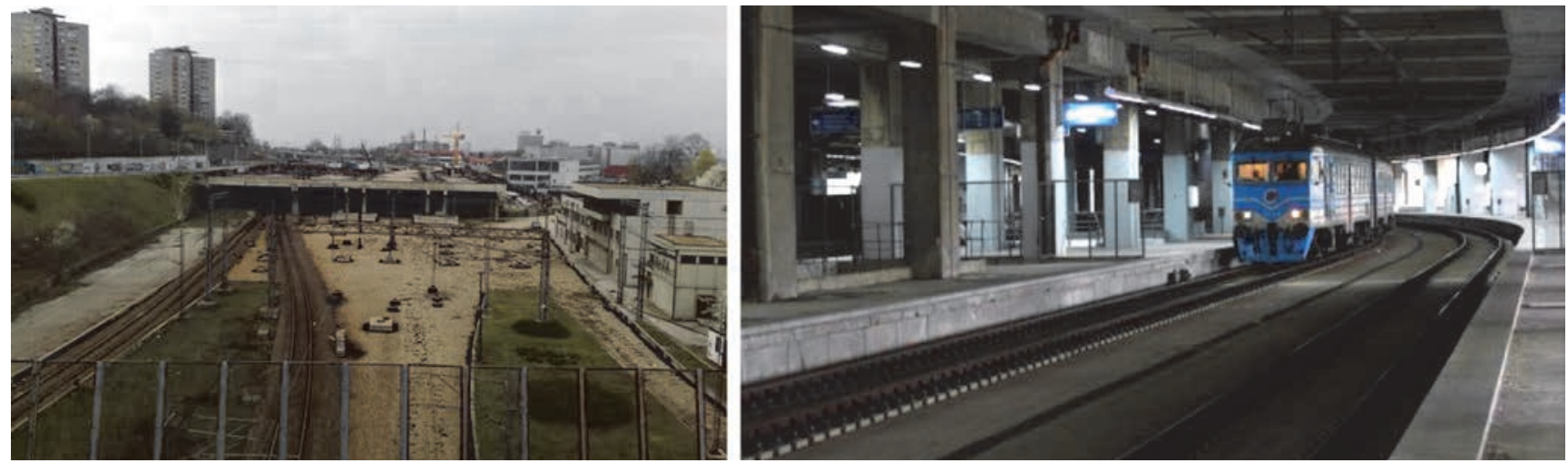

Slika 8. Kolodvor u Prokopu: a) nedostatne gradevine; b) postojeća infrastruktura

Završavanjem kolodvora u Prokopu i nadgradnjom kolodvora Novi Beograd, taj bi prostor dobio adekvatne sadržaje na ekskluzivnoj lokaciji uz rijeku, a zdanje starog Glavnog kolodvora, kao dio graditeljskog nasljeda, bilo bi adekvatno tretirano uz fleksibilnost namjene, [24].

$U$ prilog navedenom su i prognoze predvidenog prometa vlakova kroz Beogradski željeznički čvor. Zbog dugogodišnje nestabilne društveno-političke situacije i stagnacije razvoja, prekinute su i osnovne zakonitosti na kojima se zasnivaju prognoze. Međutim kombinacijom metoda, faktora i postojećih projekata i studija, prema podacima profesora Veskovića s Prometnog fakulteta, pod uvjetom da se željeznica solidno revitalizira i modernizira, predvida se da će 2020. godine kroz Beogradski željeznički čvor prolaziti 35 međunarodnih vlakova (s tranzitom), oko 18 daljinskih i 37 regionalnih. Predvida se 67 gradskih vlakova (Beovoz) te desetak prigradskih vlakova u raznim pravcima.

Kolodvor u Prokopu, započet još prije 40 godina, predviden je kao budući Glavni kolodvor željezničkog čvora Beograda. U urbanističkom smislu planiran je da bude veliko prometno čvorište koje objedinjuje željeznicu, cestu i metro, s tendencijom da postane novi gradski centar. Sadržaji u okruženju predviđaju velik broj korisnika: sajam, kliničko-bolnički centar, stadioni i stambene zone. Očekuje se da dnevni promet putnika bude oko 40.000, odnosno oko 250 pari vlakova (oko 200 lokalnih i gradskih i oko 130 direktnih i tranzitnih). Ovaj kolodvor je dobro povezan s gradskim prometnicama i nalazi se u centralnoj zoni grada. Projektiran je za deset kolosijeka i šest perona te je predvidena suvremena kolodvorska zgrada u okviru poslovno-komercijalnog kompleksa [11]. Kolodvor je znatnim dijelom izgraden u smislu željezničke infrastrukture i trenutačno je u funkciji postaja ali samo za kompozicije gradske željeznice (slika 8.). Kad bude konačno izgrađen, putnički će se željeznički sustav staviti u funkciju. Nedostatak je tog kolodvora dugogodišnje nedovršeno stanje, nedovoljna opremljenost zgrada te prijeko potrebni prometni pristupi i veze s drugim vidovima gradskog prometa. Razlozi za takvo stanje leže u ekonomskopolitičkoj situaciji, kako na nivou grada tako i na državnom nivou. Ova situacija čini da su svi na gubitku, a kolodvor je i dalje predmet izmjena i usuglašavanja stavova i projekata [20, 11].

Usprkos navedenim činjenicama, kolodvor u Prokopu posjeduje dobar urbanističko-prostorni potencijal, naročito danas s naraslim gradom. Kolodvor je prolaznog tipa u usjeku, $\mathrm{s}$ visinskom denivelacijom od 30 metara i s dvostranim prometnim pristupom, s gornjeg nivoa Dedinjskog bulevara i donjeg, s autoceste Beograd-Zagreb. Takva lokacija omogućila je koncipiranje sofisticiranog prometnog punkta, pristupačnog iz većine pravaca i dijelova grada. Prostranost lokacije u planu, omogućava da se formiraju trgovi obostrano u odnosu na središnje veliko predvorje, što sve ukupno čini da je protočan sa svih strana i prometno rasterećen. Multifunkcionalna predvorja centralnog dijela kolodvora, planirana su iznad peronskog prostora i vezni su element svih dijelova kolodvora. Morfologija terena i sam kompleks učinit će da kolodvor postane svojevrsni "belvedere" k centralnoj gradskoj panorami (slika 9.).

Prateći povijest idejnih rešenja za ovaj kolodvor, još od prvog koncepta iz 1975. godine, to je kolodvor vertikalnog plana s jedinstvom cjeline u pojavnom smislu. Nalazeći se na obodu užeg centra i sa zonom rezidencijalnog stanovanja u zaledu, danas je predvideno da bude centar tog dijela

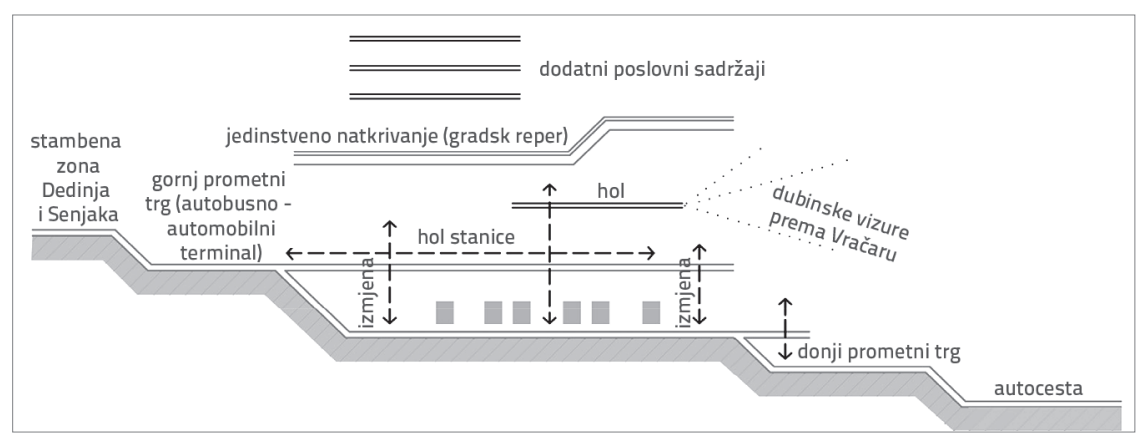

Slika 9. Poprečni profil kompleksa kolodvora Prokop s pretpostavljenom dispozicijom osnovnih namjena i potencijalom središta multimodalnog prometa 

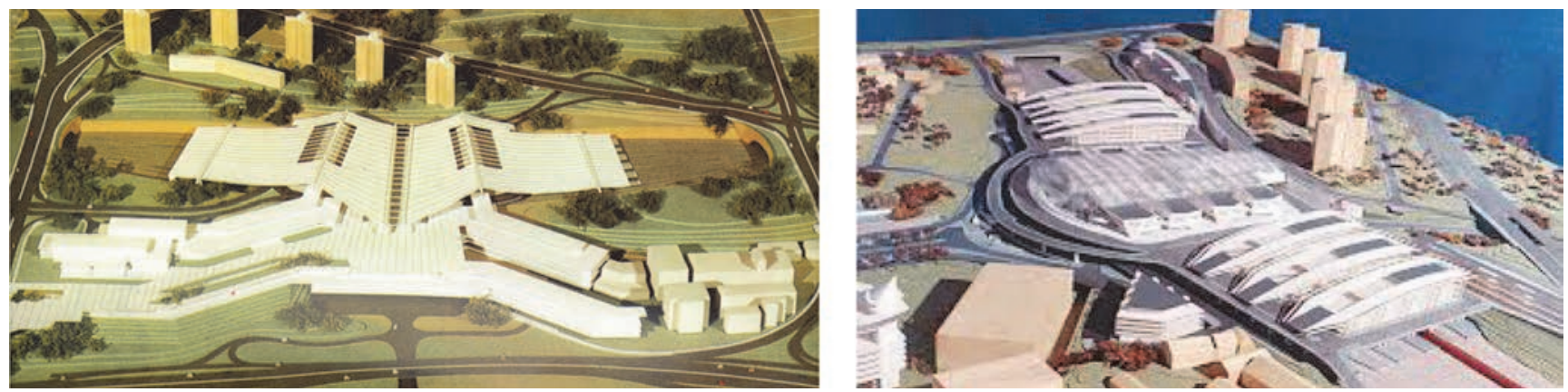

Slika 10. Najstariji (1975.) i najnoviji prijedlog rješenja željezničkog kolodvora u Prokopu u svemu prema standardima suvremenih ostvarenja kako u prošlosti, tako i danas
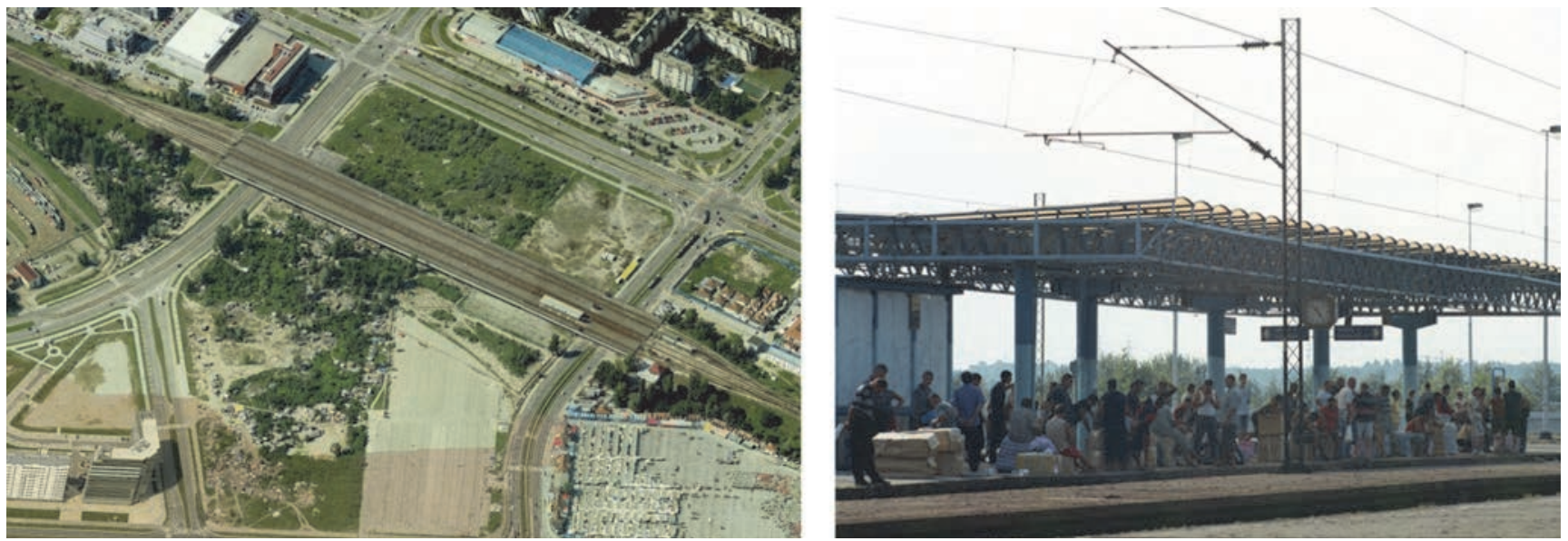

Slika 11. Kolodvor Novi Beograd: a) cjeloviti prikaz lokacije; b) nedostatak pratećih kolodvorskih sadržaja

grada i da osim prometne funkcije ponudi niz poslovnih i komercijalnih sadržaja koji nedostaju tom dijelu grada. Iskorišteni potencijali lokacije kao i principi koncipiranja ovog kolodvora opravdavaju nadanja da će Beograd imati dovršen multimodalni željeznički kolodvor u rangu suvremenih u razvijenom svijetu. U pogledu arhitektonskog izričaja, takve su gradevine ogledalo najnovijih arhitektonskokonstruktorskih dostignuća, stvarane u duhu vremena i odredene da budu dugotrajna prostorna tekovina jedne zajednice i društva (slika 10.), [25].

Kada se razmatra stanje željezničkog kolodvora Novi Beograd, njegova odlična pozicija i potencijal lokacije su nedovoljno iskorišteni (slika 11.). Kolodvor se nalazi u središnjem dijelu Novog Beograda, u zoni gdje se po GUP-u predvida formiranje centra ovog dijela grada. On je dio putničkog čvora i kroz njega prometuju vlakovi iz pravca sjevera, odnosno zapada prema Glavnom postojećem kolodvoru i kroz kolodvor Beograd Centar. Kolosijeci su vodeni nadzemno, ispod oba kraja perona nalaze se prometnice širokog profila (slika 11.). U okviru ovog područja već godinama postoji trgovački centar na otvorenom kao i veliko površinsko parkiralište. U blizini kolodvora nema izgrađenih građevina, tako da ni buka neće biti ograničavajući faktor za realizaciju ovog projekta. Korisnicima kolodvora nedostaje osnovni komfor adekvatnog peronskog zaklona, kolodvorske zgrade i prateći sadržaji.
Prema planovima za razvoj grada i prometa, predvideno je da se u zoni ovog kolodvora nade i autobusni kolodvor koji je zasad u području Savskog amfiteatra, a takoder se razmatra plan da taj kolodvor postane jedna od glavnih kolodvora u gradu kako bi se željeznički promet rasteretio i optimalno rasporedio, [26]. Kako ne postoji temeljni plan koncipiranja cjelokupnog kompleksa željezničkog kolodvora i glavnog autobusnog kolodvora, odnosno njihove sprege, utoliko prije, dobro je da se predoče potencijali formiranja kolodvora na ovakvoj lokaciji. Prostrana i neizgradena lokacija, s osiguranim prometnim prilazima i raznim oblicima gradskog prijevoza, tramvajske i autobusne linije kao i taksi stajališta, daje mogućnost da se lako formira gradsko multifunkcionalno prometno središte većih razmjera. Pristupačnost kolodvora dodatno je uvećana izgradnjom mosta na Savi preko Ade (slika 6.). Novi Beograd na ovakvom bi mjestu velikog broja sadržaja i protoka ljudi dobio novi centar razvoja, ako ne i glavni, budući da se on danas "seli" kad god nikne neki novi trgovački centar, [27]. Na temelju istraživanja potencijala kolodvora Novi Beograd iskristalizirale su se sljedeće glavne prednosti:

- kolodvor ne remeti uličnu matricu i pristupačan je drugim vidovima prometa i korisnicima (veći komfor, ušteda vremena),

- uočljiv je iz više smjerova, što je dobro za orijentaciju i sigurnost, 
- pruža vizuru na sve strane prema Novom Beogradu, a pristizanjem na perone postiže se ugodan psihološki doživljaj,

- vidljiva je dinamika kretanja unutar kolodvorskog kompleksa čime kolodvor postaje svojevrsna gradska pozornica.

Prerastanje kolodvora Novi Beograd u kompleksni gradski terminal, osim nabrojenih prednosti postojeće situacije, nameće dodatne zahtjeve i usuglašavanje:

- prilaz kolodvoru treba osigurati s oba kraja perona,

- ispod kolodvora u podzemnom nivou moguće je formirati parkiralište velikog kapaciteta i osigurati brzu vezu sa željeznicom kao i "park \& ride" sustav,

- treba osigurati dobru orijentaciju i brzu vezu s jednog na drugi nivo,

- kolodvor treba biti obogaćen dodatnim poslovnokomercijalnim sadržajima s ciljem da postane prepoznatljiv motiv grada,

- peronski prostor treba biti u potpunosti natkriven čime će osigurati potreban komfor i zaštitu putnika, (slika 12.).

Upravo sadašnji potencijal ovih lokaliteta pruža mogućnost da se formiraju reprezentativni kolodvorski kompleksi, a time doprinese formiranju gradske matrice.

\section{Zaključak}

Preporod željezničkog putničkog prometa u svijetu i izgradnja velikog broja suvremenih kolodvora, najnovijih standarda i rješenja s jedne strane, i stanje, stagnacija željeznice u regiji, s druge strane, inicirali su istraživanje morfoloških potencijala za koncipiranje željezničkih kolodvora u središnjem području Beograda.

Analiza prepoznaje prednosti kolodvora prolaznog tipa, te zahtjeve i iskustva kolodvora posljednje generacije, navodi ih $\mathrm{i}$ tumači kroz primjer beogradskih kolodvora.

Stanje najvažnijih kolodvora na području Beograda pokazuje da je upravo nastupio trenutak da se suvremena iskustva primijene u projektiranju i završetku nadgradnje željezničkog kolodvora Beograd Centar u Prokopu i kolodvora Novi Beograd, kako bi se oslobodilo područje savske obale opterećene tehničkim kolodvorskim postrojenjima iz 19. stoljeća.

Istraživanje ide u prilog tome kako odrediti prostorne aspekte u oblikovanju rješenja, koji su dio multidisciplinarne aktivnosti pri koncipiranju kolodvora u općem smislu, a s aspekta lokalne razine, to je jedan od uvjeta rješavanja dilema i donošenja konačnih odluka za odredivanje oblika navedenih kolodvora.

\section{Zahvala}

Ovaj rad je nastao kao rezultat istraživanja u okviru znanstvenog projekta: "Prostorni, ekološki, energetski

Ovakva situacija, odnosno cjelokupno stanje željeznica u Srbiji ali i u regiji, čini da je ovaj vid prometa, iako prijeko potreban, nekomforan i neatraktivan za korisnike, a najvažniji terminali Beograda devastirani i neoformljeni urbani prostori. i društveni aspekti razvoja naselja i klimatske promene medjusobni uticaji" (TR 36035), koji je u okviru programa Tehnološki razvoj financiralo Ministarstvo prosvete, nauke i tehnološkog razvoja Republike Srbije (2011.-2014.).

\section{LITERATURA}

[1] Girardet, H.: "Sustainable Cities: A Contradiction In Terms?" in The Earthscan Reader In Sustainable Cities (ed. Satterthwaite, D.), Earthscan Publications, London, 1999.

[2] European Commission, White Paper - Roadmap to a Single European Transport Area - Towards a competitive and resource efficient transport system, Brussels, Belgium, 2011.

[3] European Commission, White Paper - European Transportation Policy for 2010: time to decide, Office for Official Publications of the European Communities Luxembourg, 2011.
[4] Calthorpe, P.: Urbanism in the age of climate change, Island Press, Washington DC, 2011.

[5] Maletin, M.: Gradske saobraćajnice, Gradjevinski fakultet u Beogradu, 2005.

[6] Blow, C.: Transport Terminals and Modal Interchanges, Architectural Press Oxford, 2005.

[7] Richards, B.: Future transport in cities, Spon Press, London, 2001. 
[8] Stevanović, K.: Održivi razvoj gradova - transport, savremeni železnički terminali, Arhitektura i urbanizam, no. 22/23, IAUS, Beograd, 2008.

[9] Ventura, P.: Citta e Stazione Ferroviaria, Firenze University Press-EDIFIR, 2004

[10] Binney, M.: Architecture of rail, Academy Edition, London, 1995.

[11] Beogradski željeznički čvor, http://www.sicip.co.rs /

[12] Janjič, S.: Željezničke stanice 1, Gradevinski fakultet Beograd, 1983.

[13] Stevanović, K.: Putnički željeznički terminali u funkciji unapređenja urbane matrice, doktorat, Arhitektonski fakultet u Beogradu, 2010.

[14] Dobrović, N.: Tehnika urbanizma - Promet, Naučna knjiga, Beograd 1957

[15] Stevanović, K.: Renesansa železničkih terminala, Zadužbina Andrejević, Beograd, 2008.

[16] Meeks, C.: The railroad station, Dover Publication NY, 1956.

[17] Ferrarini, A.: Railway Stations, Electa architecture, 2005.

[18] Ross, J.: Railway Stations-Planning, Design \& Management, Architectural Press, Oxford, 2000.

[19] Popović, Z., Puzavac, L., Lazarević, L.: Improving the accessibility of passenger railways in the Republic of Serbia, RTR - Rail Technology Review, Vol. 52, 2012, No. 2, pp. 25-29
[20] Generalni plan Beograda 2021, Promet i infrastruktura, Urbanistički zavod Beograda, 2003. http://mapa.urbel.com/ silverlight/gp/?src=saobracaj

[21] Strategija regionalnog razvoja Republike Srbije za period od 2007. do 2012. god, Vlada RS, "Službeni glasnik RS", br. 55/05 i 71/05 https://www.google.rs/\#q=projekat+beograd+na+vodi+ politik

[22] Renaissance of Railway Stations, Bund Deutcher Architekten, Deutche Bahn, Deutches Architekturzentrum 11, 1996.

[23] Galan Gonzalez, A., Stevanović, M., Acha Roman, C., Bouillard, P.: Keeping the historical heritage alive, PLEA2013 - 29th Conference - Sustainable Architecture for a Renewable Future, Munich, Germany, 2013, http://mediatum.ub.tum.de/?change_ language $=e n$

[24] Kincl, B., Neidhardt, V., Radić, J., Vlašić, A., Mujkanović, N.: Konstrukcija novog putničkog terminala zagrebačkog aerodroma, GRAĐEVINAR 64 (2012) 6, pp. 475-484.

[25] http://www.politika.rs/rubrike/Beograd/t50736.lt.html

[26] Stevanović, K, Popović, Z.: Sustainable urban developmentTerminal Novi Beograd-Morphological potental, Sustainable urban \& transport planing International Conference 2013, Beograd, pp. 256-270, 2013. 